\title{
Evaluation of New Strains Produced From Pineapple (Ananas comosus) Var. Cayeen Treated with Colchicine
}

\author{
N. H. Nady \\ Tropical Fruits Research Department, Horticulture Research \\ Institute, Agricultural Research Centre, Cairo, Egypt.
}

\begin{abstract}
7 HIS STUDY was carried out during 2013 and 2014 seasons in order to evaluate 14 pineapple strains resulted from colchicine treatment of pineapple plants grown in the orchard of Horticulture Research Orchard, Agriculture Research Center. Giza. Egypt, in comparison with the original cultivar Cayeen. Fruit characteristics, as physical and chemical properties of fruit were recorded. Morphological characteristics for leaf edges, fruit, crown and flowers were, also, studied. Results demonstrated that, total fruit weight (fruit+crown) was the highest with strain no. 9 in comparison with other tested strains, as well as "Cayeen" cv. Regarding, fruit physical properties, strain no. 9 recorded the heaviest fruit weight $900 \mathrm{~g}$ as compared to $462.5 \mathrm{~g}$ for the original cultivar (Cayeen) with an increase of $94.6 \%$ for fruit weight. Concerning fruit chemical properties, data indicated no significant differences in fruit juice T.S.S\% and total sugars content. General evaluation revealed that strain no. 9 seemed to be the superior strain regarding fruit quality among all the tested strains, as it attained the uppermost score as compared with the standard cv." Cayeen". The morphological evaluation showed that it has smooth leaf. Dormant flowers were recorded in the in inflorescences of some strains and the strains no. 17 and 31 were advised for further study in breaking dormant flowers.
\end{abstract}

Thus, It can be concluded that the selected strain no. 9 has good fruit quality for consumer and strains no. 17 and 31 needs further studies concerning flower dormant activation.

Keywords: Pineapple, Colchicine, Breeding, Strains.

World consumption of fresh pineapple has quadrupled in less than 10 years (Loeillet et al., 2011). This phenomenal event started around 1996 when the first dedicated fresh market pineapple, '73-114', was released by Del Monte Inc. This was the culmination of somewhere in the vicinity of 34 years of breeding and selection and comprised 24 individual parent combinations (Anon., PRI breeding records). This demonstrates the difficulty of breeding new pineapple cultivars but also the value of a successful program. The success of '73-114' and the competitive nature of world pineapple markets have provided impetus for pineapple breeding programs. However, the highly heterozygous nature and self-incompatibility of pineapple limit breeding strategy options. (Sanewski et al., 2011) 
Polyploidy plants can be promising source for plant breeding. In this regard Hannweg et al. (2012). Polyploid plants can arise naturally from the duplication of chromosomes of a single species (autoploidy) or the combination of two or more chromosome sets of different species (alloploidy). Generally, induced autopolyploids are expected to have at least one of the following characteristics which would result in the improvement, or development of new economically important plants, larger tuber, rhizome or root size, increased fruit size, enhanced flower size and/or colour intensity, improved drought tolerance, increased biomass, improved photosynthetic capacity, larger and/or thicker leaves, dwarfism, increased secondary metabolite production e.g. medicinal compounds.

Ploidy manipulation is a renowned source of germplasm development for citrus crop improvement. In vitro culture offers the novel methods of creating polyploid plants (Hannweg, 1999, Starrantino, 1999, Ollitrault et al., 2000 and Zhang et al., 2007). Polyploids could be developed using strategies like in vivo and in vitro application of colchicine for doubling the chromosome number (Hannweg, 1999), interploid crossing followed by embryo rescue plantlets have been successfully recovered in several tree genera using endosperm culture in vitro including Citrus (Mooney et al., 1996 and Ollitrault et al., 1996a) Malus (Mu and Liu, 1979), Prunus (Liu and Liu, 1980), Actinidia (Gui et al., 1982), Pyrus (Zhao, 1983) and Morus (Thomas et al., 2000). The availability of limited gene pool and polyploidy germplasm for breeding and biotechnology programs suggests intensive research work in this important area. Therefore, both strategies were explored for polyploid development in elite citrus cultivars using colchicine application in vivo and endosperm culture in vitro. The generated polyploids will contribute towards enrichment of Citrus germplasm for future breeding and biotechnology applications. Scherer et al. (2015), The 'Gigante de Tarauacá' is a native pineapple that produces large fruits (as much as $15 \mathrm{~kg}$ ) in the region of Tarauacá, Acre State, Northern Brazil. Hypothesizing that this feature is related with polyploidy.

In Egypt many publications reported that pineapple fruits was too small to be recommended in cultivation (Nady, 2010).

The aim of this study was to produce and evaluate new strains for fresh market with improved fruit quality through inducing polyploye plant by using colchicine.

\section{Materials and methods}

This study was carried out in Giza governorate during the period of (20112015) to induce (by colchicines treatments) and evaluate new strains of pineapple produced from the original cultivar Cayenne.

In vitro Cayenne pineapple in shooting stage was employed for this study, pineapple shoots clusters were planted on a medium comprised of Murashige and Skoog (MS) (1962) salts with $0.5 \mathrm{mg}^{-1}$ thiamine $\mathrm{HCl}, 0.5 \mathrm{mg}^{-1}$ pyridoxine, $0.5 \mathrm{mg}^{-1}$

Egypt. J. Hort. Vol. 42, No. 2 (2015) 
nicotinic acid, $100 \mathrm{mg}^{-1}$ myo-inositol, and $30 \mathrm{~g}^{-1}$ sucrose. This medium was supplemented with $2 \mathrm{mg}^{-1} \mathrm{BA}$ and $0.7 \%$ (w/v) Diffico agar. The $\mathrm{pH}$ was adjusted before agar addition to 5.6 with either $0.1 \mathrm{M} \mathrm{KOH}$ or $0.1 \mathrm{M} \mathrm{HCl}$. Media were autoclaved for $15 \mathrm{~min}$ at $121{ }^{\circ} \mathrm{C}$ and $103 \mathrm{kPa}$. Explants were cultured in $300 \mathrm{ml}$ glass jars containing $50 \mathrm{ml}$ media. Cultures were maintained at $27 \pm 3^{\circ} \mathrm{C}$ under 3000 lux from cool white fluorescent tubes with a $16 \mathrm{hr}$ photoperiod.

The treatments: colchicine was added to the medium before autoclaving in concentrations of 5, 10 and $15 \mathrm{ppm}$.

Produced plants were acclimatized and grown in greenhouse until suitable size then transplanted in sandy soil prepared especially in the open field.

TABLE (A) strains produced from colchicine concentrations.

\begin{tabular}{|c|c|}
\hline Colchicine concentrations & Strains produced \\
\hline $5 \mathrm{ppm}$ & $4,9,11,15,1$ \\
\hline $10 \mathrm{ppm}$ & $17,23,31,3234,33,26,36,35$ \\
\hline $15 \mathrm{ppm}$ & $51,53,40,42,47$ \\
\hline
\end{tabular}

Experimental design and measurements: The randomized complete design was adopted for this experiment. Three jars, each containing six clusters of five shoots evenly spaced within the jar, were used for each treatment. At the end of the experiment the following data were taken, physical and chemical properties of fruits. Representative fruits were taken at full ripe stage. Fruit evaluation included weight of both fruit, crowen and peel, fruit dimensions, and pulp\% were measured. Total soluble solids T.S.S \% in the pulp using a hand referactometer. Acidity was determined according to the method described in the A.O.A.C (1985). Total and reducing sugars content were determined according to Lane \& Eynon volumetric procedure as out lined in A.O.A.C. (1985).

Vitamin C determination: $5 \mathrm{ml}$ of juice of ripen pineapple fruits were mixed with $5 \mathrm{ml}$ of $2 \%$ oxalic acid in test tube and titreated with 2, 6 dichlorophenol indophenol $(50 \mathrm{mg} / 250 \mathrm{ml}$ of warm distilled water) until rosy colour appeared (y ml). Titrations repeated with $10 \mathrm{ml}$ from vitamin $\mathrm{C}$ solution $10 \mathrm{mg} / 250$ of $2 \%$ oxalic acid (x ml). Vitamin C concentration, according A.O.A.C. (1960), in $\mathrm{mg} / 100 \mathrm{ml}$ of juice calculated according to the following equation:

\section{Vitamin $\mathrm{C}=8 \mathrm{Y} \div \mathrm{X}=\mathrm{mg}$ Vitamin $\mathrm{C} / 100 \mathrm{ml}$ of juice}

Statistical analysis: The statistical analysis of the collected data were carried out according to Snedecor and Cochran (1980). Means were compared using the new L.S.D. values at $5 \%$ probability level. Percentages were transformed to arcsines prior to the statistical analysis. 
The final evaluation of any tested strains was calculated on the basis of 100 units (Hussein et al., 1982) which were shared between fruit weight (50 units) and fruit quality (50 units). The latter units were divided on the basis of 10 units for each of Vit C, pulp\%, T.S.S and total sugar percentage and the percentage of acidity.

Each pineapple strain that gave the best results in any character got the maximum value specified for this character, while each of the other tested strains took lower units equal to their quality. For instance if strain no. 9 produced the highest yield it will have the 50 units specified for this character accordingly by units of any other tested pineapple strains for the same character could be calculated as follows:

$$
50 \times \text { fruit weight of tested strain }
$$

Fruit weight of strain no. 9

Similarly, units for any concerned character were calculated in the same way.

\section{Results and Discussion}

\section{Physical fruit properties}

Data in Table 1 show a comparative study for physical fruit properties of various strains resulted from colchicine treatments. Data clearly showed that:

Fruit length: strain no. (9) was significantly the tallest fruits $(9 \mathrm{~cm})$ flowed by strain no. $11(7.5 \mathrm{~cm})$, the length of strains no. 4,23 and 26 was $7 \mathrm{~cm}$, the other strains were shorter than $7 \mathrm{~cm}$.

Fruit diameter: the strain no. 11 recorded the highest significant value for fruit thickness. It reached $(9.5 \mathrm{~cm})$ in diameter followed by the strains no. 9 and 26 the fruit diameter was $(9 \mathrm{~cm})$ while for all other strains the values were thinner.

Total fruit weight: it is clear from the data in Table 1 that strain no. 9 had the heaviest fruit weight $(900 \mathrm{~g})$ followed by strain no. 4 (694g) while all other strains showed a smaller fruit weight values ranged from 295 to $490 \mathrm{~g}$.

Fruit weight: the strain No. 9 was the heaviest fruit $(703 \mathrm{~g})$ flowed by strain No. 4 (494 g). All other strains showed a smaller fruits ranged from 244 to $425 \mathrm{~g}$.

Crown weight: the largest crowns (200g) recorded for the strain no. 4 flowed by $(197 \mathrm{~g})$ for the strain no. 9 . The other strains crowns were smaller and ranged fro $\mathrm{m} 60$ to $150 \mathrm{~g}$.

Berries number: highest berries number (45) was recorded for the strains no. 9 followed by 39, 38, 33, 31 and 30 for strains no. 11, 23, 36, 26 and 33, respectively. All other strains showed a smaller number of berries.

Egypt. J. Hort. Vol. 42, No. 2 (2015) 


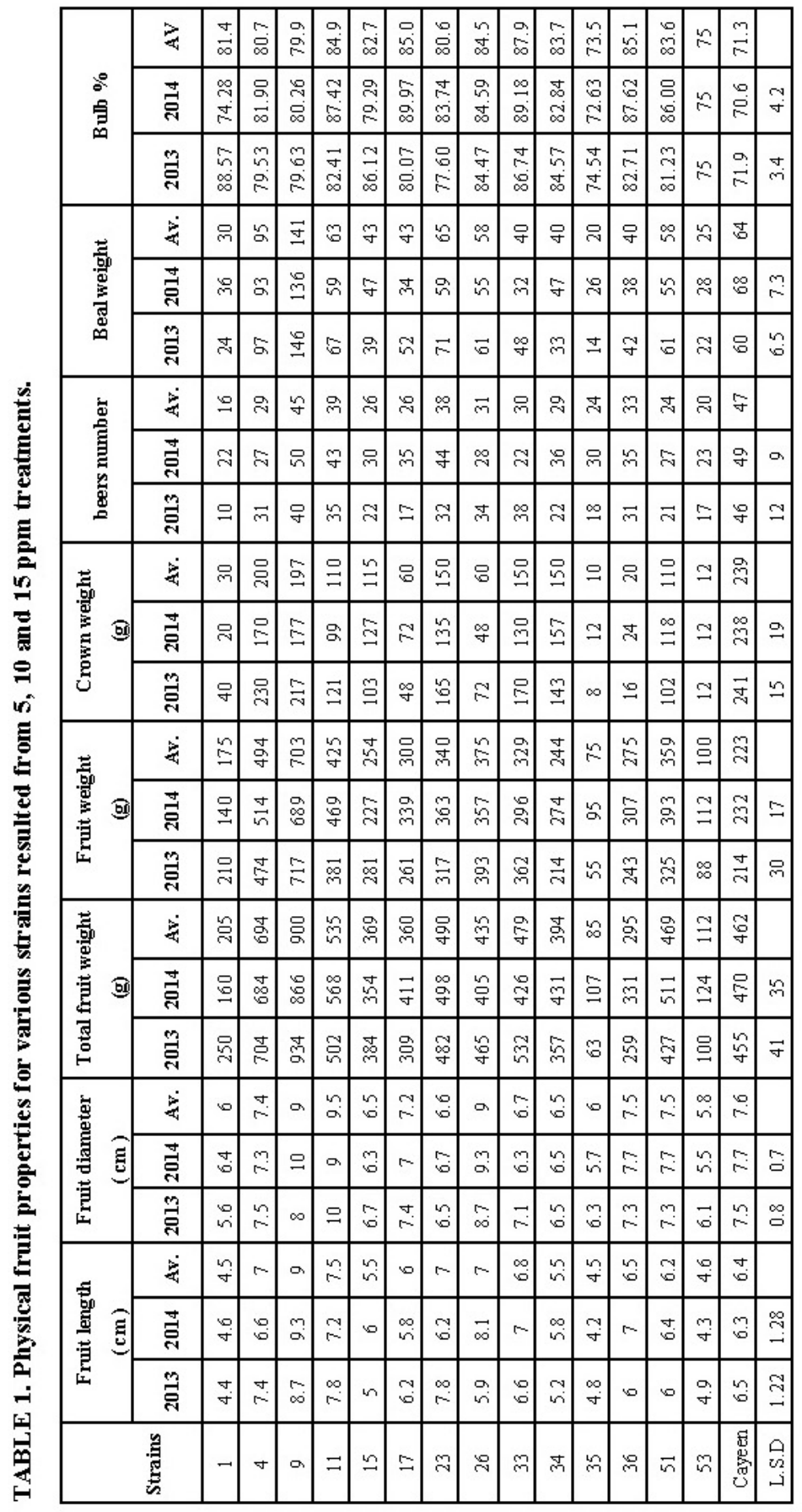

Egypt. J. Hort. Vol. 42, No. 2 (2015) 
Peel weight: highest peel weight (141g) was recorded for the strains no. 9 followed by $95 \mathrm{~g}$ for the strain no. 4 , the other strains peel weight ranged from 40 to $65 \mathrm{~g}$.

Bulb \%: there were no significant differences among the studied strains. The highest value $(87.9 \%)$ was recorded for the strain no. 33. whereas, the lowest values (73\% and $75 \%)$ were recorded for the strains 35 and 53, respectively. All other strains were in range of $79.9 \%$ to $86.1 \%$. Hannweg et al. (2012) mentioned that induced autopolyploids, expected to have at least one of the following characteristics, larger tuber, rhizome or root size, increased fruit size, enhanced flower size and/or colour intensity, improved drought tolerance, increased bio-mass, improved photosynthetic capacity, larger and/or thicker leaves, dwarfism, increased secondary metabolite production e.g. medicinal compounds. Scherer et al. (2015) mentioned that the 'Gigante de Tarauacá' is a native pineapple that produces large fruits (as much as $15 \mathrm{~kg}$ ) in the region of Tarauacá, Acre State, Northern Brazil.

Hypothesizing that this feature is related with polyploidy, ploidy levels identified in the histograms by flow cytometry revealed the triploid nature of the 'Gigante de Tarauacá' $(2 \mathrm{n}=3 \mathrm{x}=75)$ and the diploid status of 'Pérola' $(2 n=2 x=50)$. To the best of our knowledge this is the first report of the triploid nature of the 'Gigante de Tarauacá'.

Cabral et al. (2009) mentioned that the main constraint of the pineapple crop in Brazil, with good fruit quality and spineless leaves. Cabral and Matos (2009) stated that the 'Imperial' pineapple plant is of intermediate height with spineless dark green leaves. The fruit is small and cylindrical. The following characteristics may be considered as unfavourable: slow plant growth, peduncle with small diameter, small fruit $(1.6 \mathrm{~kg})$,

\section{Chemical fruit properties}

Data In Table 2 showed a comparison among various strains resulted from in vitro colchicine treatments in chemical fruit properties.

Vitamin C: data clearly showed that there were no significant differences in vitamin $C$ in various strains. The highest insignificant value $(45 \mathrm{mg} / 100 \mathrm{~g})$ recorded for the strain no. 11 , and the lowest value $(32 \mathrm{mg} / 100 \mathrm{~g})$ recorded for the strain no. 4. All other strains came in range of ( 34 to $43 \mathrm{mg} / 100 \mathrm{~g}$ )

Although the range was wide but data were not significant that pineapple chemical fruit properties are hardly affected by climatic conditions Joomwong (2006) showed that the fruit harvested in winter had the highest content of total soluble solid (TSS) and titratable acids (TA), and the lowest TSS acid ratio than any other seasons. However, the correlation between development and sugar metabolism in the 'smooth cayenne' cultivated in the different harvest seasons is yet unknown.

Egypt. J. Hort. Vol. 42, No. 2 (2015) 
Acidity: data clearly showed that there were no significant differences in acidity value. The highest value for acidity was $(1220 \mathrm{mg} / 100 \mathrm{~g})$, recorded for strain no. 11 and the lowest $711 \mathrm{mg} / 100 \mathrm{~g}$ for the strain no. 53. All other strains were in range of $800 \mathrm{mg} / 100 \mathrm{~g}$ to $1140 \mathrm{mg} / 100 \mathrm{~g}$.

Total sugars: data showed that there were no significant differences among all studied strains. The highest value for total sugars 30 recorded for the strain no. 51 and the lowest value was 23 the strain no. 1 all other strains came in between they ranged from 24 to 26 in very narrow range.

Reducing sugars: it is clear from data in Table 2 show that there were no significant differences among all studied strains in reducing sugars. Data showed that highest value 9 recorded for the strain no. 15 and the lowest insignificant value 7.9 recorded for strains no. 53. Others strains were in narrow range of 8 to 8.4.

Non reducing sugars: data showed that there are no significant differences among all studied strains. Highest insignificant value for non reducing sugars 21.7 recorded for the strain no. 51 and the lowest insignificant value 14.1 recorded for the strain no. 1. All studied strains were in wide range of 14.1 to 21.6.

Fruit taste and quality depends on factors such as sugars, organic acids, firmness, amino acids and aromatic compounds. Sugars synthesized in source tissues are one of the most important sugars, which are transported into sink tissues such as fruit, shoots and other tissues (Itai and Tanahashi, 2008).

Joomwong (2006) stated that the fruit harvested in winter had the highest content of total soluble solid (TSS) and titratable acids (TA), and the lowest ratio of TSS: TA than any other seasons. However, the correlation between development and sugar metabolism in the 'smooth cayenne' cultivated in the different harvest seasons is yet unknown.

Zhang et al. (2011) mentioned that in pineapple fruits, sugar accumulation plays an important role in flavour characteristics, which varies according to the stage of fruit development. Metabolic changes in the contents of fructose, sucrose,glucose and reducing sugar related to the activities of soluble acid invertase (AI), neutral invertase (NI), sucrose synathase (SS) and sucrosephosphate synthase (SPS) were studied in winter and summer

Cabral and Matos (2009) mentioned that the pulp of the 'Imperial' pineapple plant is high sugar content, moderate acidity, a high level of ascorbic acid and a very good flavour. Loison-Cabot and Lacoeuilhe (1990) mentioned that the aim of a pineapple breeding programme initiated in 1978 in Ivory Coast was to produce new cultivars for fresh and processed market with improved fruit quality (appearance, texture and taste). 


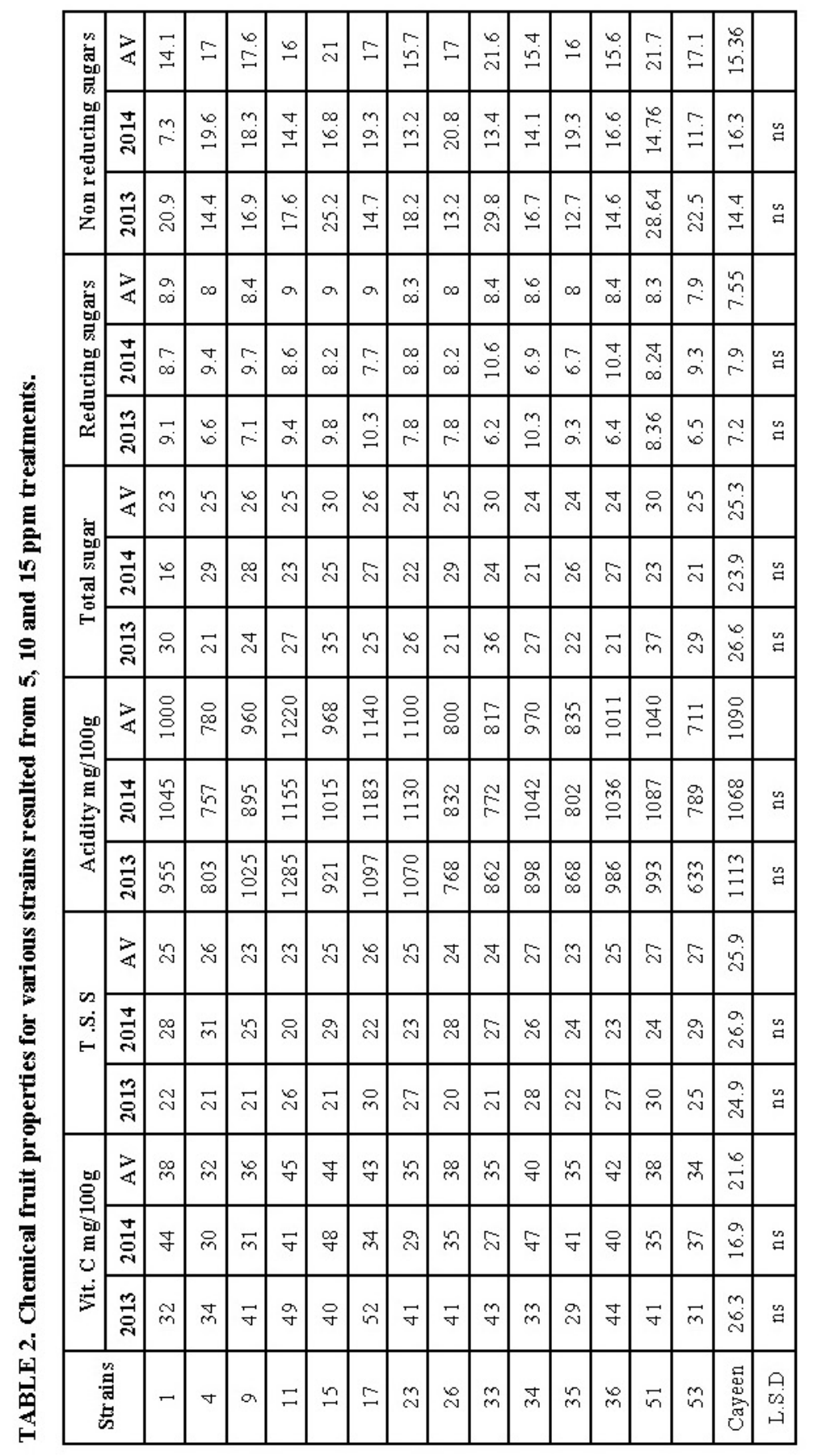




\section{General evaluation and final conclusion}

Data tabulated in Table 3 showed that pineapple strain no. 9 seemed to be the superior strain in yield and fruit quality among all the tested pineapple strains, as they attained the uppermost score units (92.1) as compared with other strains standard. On the contrary, all studied strains showed less fruit weight and the same fruit quality.

TABLE 3. Digital evaluation for various strains resulted from 5,10 and 15 ppm colchicine treatments.

\begin{tabular}{|c|c|c|c|c|c|c|c|}
\hline Strains & $\begin{array}{c}\text { Fruit } \\
\text { weight } \\
\mathbf{5 0} \text { units }\end{array}$ & $\begin{array}{c}\text { Bulb \% } \\
\mathbf{1 0} \text { units }\end{array}$ & $\begin{array}{c}\text { Vit. C } \\
\mathbf{1 0} \text { units }\end{array}$ & $\begin{array}{c}\text { T.S.S } \\
\mathbf{1 0} \text { units }\end{array}$ & $\begin{array}{c}\text { Acidity } \\
\mathbf{1 0} \text { units }\end{array}$ & $\begin{array}{c}\text { Total } \\
\text { sugar } \\
\mathbf{1 0} \text { units }\end{array}$ & $\begin{array}{c}\text { Sum } \\
\mathbf{1 0 0} \\
\text { units }\end{array}$ \\
\hline 1 & 12.5 & 9.2 & 8.4 & 9.3 & 8.2 & 7.7 & 55.3 \\
\hline 4 & 35.1 & 9.2 & 7.1 & 9.6 & 6.4 & 8.3 & 75.8 \\
\hline 9 & 50.0 & 9.1 & 8.0 & 8.5 & 7.9 & 8.7 & 92.1 \\
\hline 11 & 30.2 & 9.6 & 10.0 & 8.5 & 10.0 & 8.3 & 76.7 \\
\hline 15 & 18.1 & 9.4 & 9.8 & 9.3 & 7.9 & 10.0 & 64.4 \\
\hline 17 & 21.3 & 9.7 & 9.6 & 9.6 & 9.3 & 8.7 & 68.2 \\
\hline 23 & 24.2 & 9.2 & 7.8 & 9.3 & 9.0 & 8.0 & 67.4 \\
\hline 26 & 26.7 & 9.6 & 8.4 & 8.9 & 6.5 & 8.3 & 68.5 \\
\hline 33 & 23.4 & 10 & 7.8 & 8.9 & 6.7 & 10.0 & 66.8 \\
\hline 34 & 17.3 & 9.5 & 8.9 & 10.0 & 7.9 & 8.0 & 61.7 \\
\hline 35 & 5.3 & 8.4 & 7.8 & 8.5 & 6.8 & 8.0 & 44.8 \\
\hline 36 & 19.5 & 9.7 & 9.3 & 9.3 & 8.3 & 8.0 & 64.1 \\
\hline 51 & 25.5 & 9.5 & 8.4 & 10.0 & 8.5 & 10.0 & 72.0 \\
\hline 53 & 7.1 & 8.5 & 7.6 & 10.0 & 5.8 & 8.3 & 47.3 \\
\hline Cayeen & 25.7 & 8.1 & 4.8 & 9.6 & 8.9 & 8.4 & 65.6 \\
\hline
\end{tabular}

Thus, one can conclude that all the 14 studied strains are in a good fruit quality for consumer but only strain no. 9 showed the highest fruit weight.

Flowering characteristics: data in Table 4 showed the number of days from Etherl treatment to flower differentiation and fruit harvest for 14 strains produced from colchicine treatments.

Days to flower differentiation: data showed that there were a significant differences in number of days to flower differentiation. The lowest significant number (28 days) was recorded for the original cultivar, other strains showed a wide range from 59 to 67 days from Ethrel application to the occurrence of floral differentiation. Days to harvest: data clearly showed that there is a significant difference in number of days to harvest. The lowest number of days to harvest (144) was recorded to original cultivar. All studied strains were harvested later than original cultivar as they spent 184 to 197 days from Ethrl treatment to harvest. 
Morphological evaluation: morphological evaluation involved variation in fruit size crown size, shape and flower formation and characteristics and leaf edges spiny.

Data in Fig. (1, 2a and 2b) showed that:

- leaf edges: there were many strains of leaf edges some strains were hard spiny edges (strain 17 and 40), normal spiny (51,35, 31, 11 and 42), low spiny (46) while some strains have one leaf edge spiny and the other edge smothe (not spiny) the rest of strains were smooth leaf edges.

- Fruits: fruit varied in size and shape, the greatest were the strains (9) others were smaller and some of them have no fruits $(40,31,32,47$ and 42).

- Crown: crown varied in shape and size some crowns were tall (4, 23, 51, 34,15 and 33) others were very short $(36,17,1$ and 53) the rest of starins crown were intermediate.

Flower characteristics: many strains could not produce normal flowers that its inflorescence had only bracts and the flowers deformed $(40,31,32$, 42 and 47). Other strains contained normal flowers in addition to the deformed flowers (47). The rest of strains contained normal flowers. Two strains have a crown only with deformed bracts (32 and 47) the strain 31 showed a growth of vegetative buds from some bracts. They were flowers but converted into vegetative buds.

We can conclude that 17 and 31 could be used in further study in activating flowers in its bracts. Cabral et al. (2009) said that the main constraint of the pineapple crop in Brazil with good fruit quality and spineless leaves. Cabral and Matos (2009) reported that the 'Imperial' pineapple plant is of intermediate height with spineless dark green leaves. The fruit is small and cylindrical, with a yellow peel at ripening. The pulp is yellow, Cabral et al. (2009) both seedlings obtained from 'Perolera' have green leaves, one of them being spiny and the other spineless.

To conclude, among the tested strains, the strain no.9 proved to be the best as evidenced by its fruit weight $900 \mathrm{~g}$ and total sugars content. Strain no. 17 and 31 were advised for further study in activating dormant flowers.

It could be concluded that the selected strain no. 9 has good fruit quality for consumer and strains no. 17 and 31 are recommended to be studied in activating dormant flowers.

Egypt. J. Hort. Vol. 42, No. 2 (2015) 
EVALUATION OF NEW STRAINS PRODUCED FROM PINEAPPLE ...

\begin{tabular}{|c|c|c|c|c|c|c|}
\hline$\stackrel{\theta}{i}$ & $\stackrel{\underline{y}}{z}$ & $\stackrel{\mathscr{L}}{=}$ & & $\stackrel{n}{\exists}$ & $\stackrel{\mathscr{L}}{g}$ & \\
\hline 80 & 6 & ஜ̊ & मे & ఏ & :్ & $\stackrel{-}{\Omega}$ \\
\hline$\overline{\tilde{n}}$ & 8 & n? & $\begin{array}{l}n \\
\text { n } \\
\text { n }\end{array}$ & 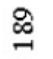 & $\stackrel{\mathscr{\infty}}{\rightarrow}$ & $\stackrel{\mathscr{0}}{0}$ \\
\hline ల్ల & 8 & 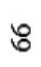 & $\frac{n}{6}$ & $\stackrel{\mathscr{O}}{\sim}$ & ఫ & $\begin{array}{c}n \\
\infty \\
\infty\end{array}$ \\
\hline 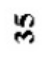 & 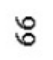 & J & $\ddot{2}$ & $\underset{-}{\infty}$ & $\underset{-\infty}{\infty}$ & 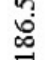 \\
\hline ले & $\hat{n}$ & $\stackrel{\infty}{\infty}$ & గ్ర & $\begin{array}{l}\infty \\
\underset{-}{\infty}\end{array}$ & & $\stackrel{8}{9}$ \\
\hline లె & $\tilde{6}$ & 8 & గ్ర & $\underset{\Phi}{\infty}$ & $\stackrel{\Omega}{\Xi}$ & $\underset{\sim}{\mathscr{\varpi}}$ \\
\hline ֻั & ర్ర & $\infty$ & 6 & $\underset{-\infty}{\infty}$ & $\underset{\sim}{\overrightarrow{0}}$ & $\underset{\sim}{\mathbb{\infty}}$ \\
\hline$\ddot{\sim}$ & $\stackrel{\infty}{\circ}$ & 8 & $\begin{array}{l}n \\
8 \\
8\end{array}$ & $\alpha$ & $\approx$ & $\stackrel{n}{2}$ \\
\hline$\Xi$ & 6 & 6 & $\sqrt{6}$ & $\underset{\sim}{\stackrel{\infty}{二}}$ & $\tilde{g}$ & @i \\
\hline$\cong$ & 8 & bे & $\begin{array}{l}n \\
\end{array}$ & $\hat{a}$ & $\stackrel{\infty}{\stackrel{\infty}{2}}$ & $\frac{n}{5}$ \\
\hline$\exists$ & J & 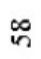 & $\overrightarrow{6}$ & $\stackrel{\infty}{\sim}$ & 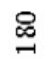 & జె \\
\hline$a$ & ஜ̊ & in & $\begin{array}{l}n \\
\text { o. } \\
\text { in }\end{array}$ & ऽ & 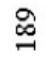 & ᄋ \\
\hline+ & $\overrightarrow{6}$ & ర్ & $\frac{n}{6}$ & $\bar{\sigma}$ & $\underset{\sim}{\stackrel{\leftrightarrow}{2}}$ & $\stackrel{ }{2}$ \\
\hline$=$ & 8 & 8 & $\begin{array}{l}\text { ñ } \\
\text { ?n }\end{array}$ & $\hat{q}$ & $\underset{-\infty}{\infty}$ & $\stackrel{9}{9}$ \\
\hline 这 & i & pి & $\stackrel{\infty}{i}$ & 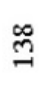 & ஜำ & $\underset{\exists}{J}$ \\
\hline 哀 & 궁 & $\stackrel{\text { m. }}{\circ}$ & 昰 & 룽 & ֻ) & Z \\
\hline 童 & \multicolumn{3}{|c|}{ 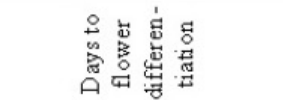 } & \multicolumn{3}{|c|}{ 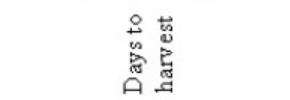 } \\
\hline
\end{tabular}

Egypt. J. Hort. Vol. 42, No. 2 (2015) 


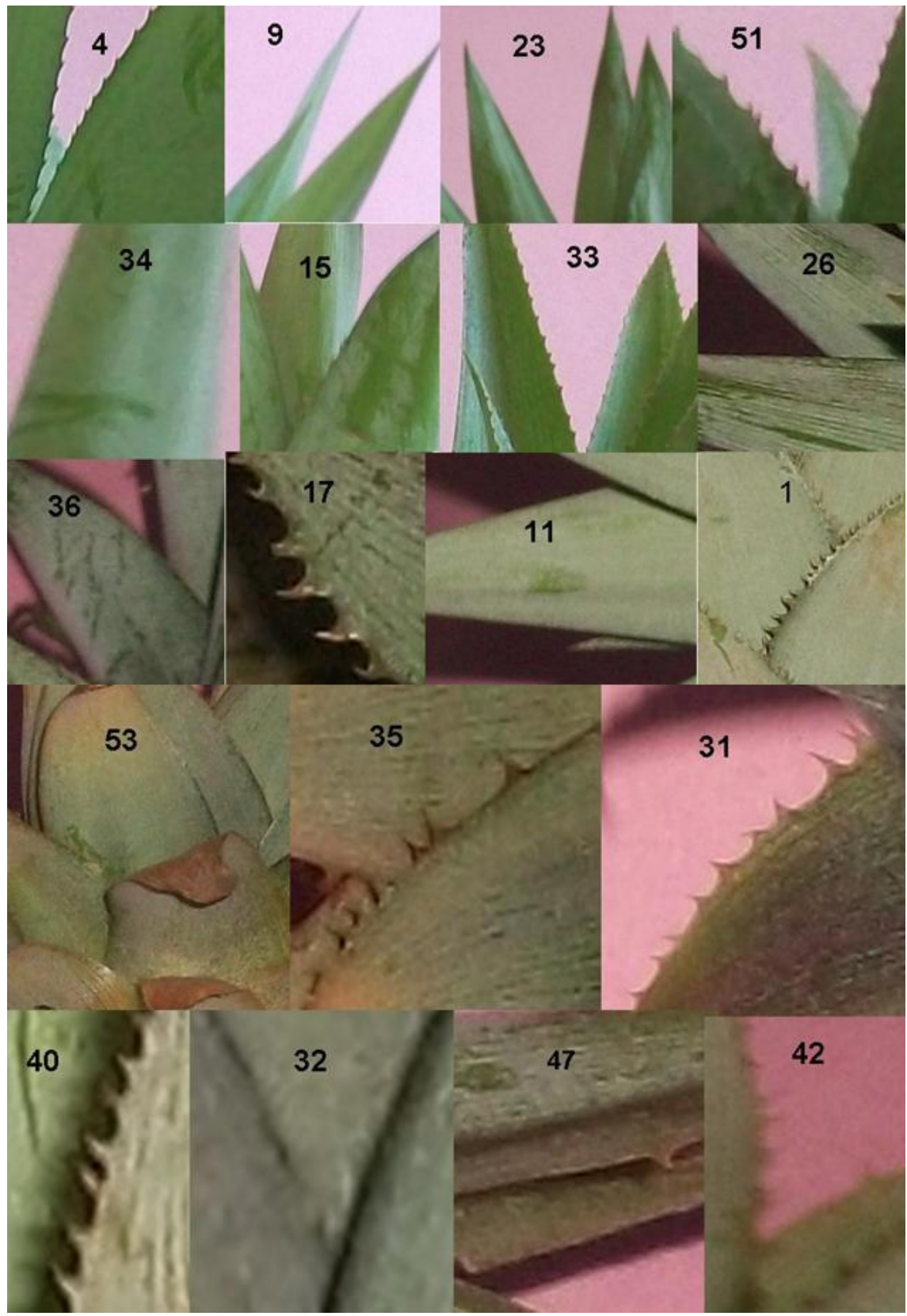

Fig. 1. Leaf evades morphological characteristics for various strains resulted from colchicine treatments.

Egypt. J. Hort. Vol. 42, No. 2 (2015) 


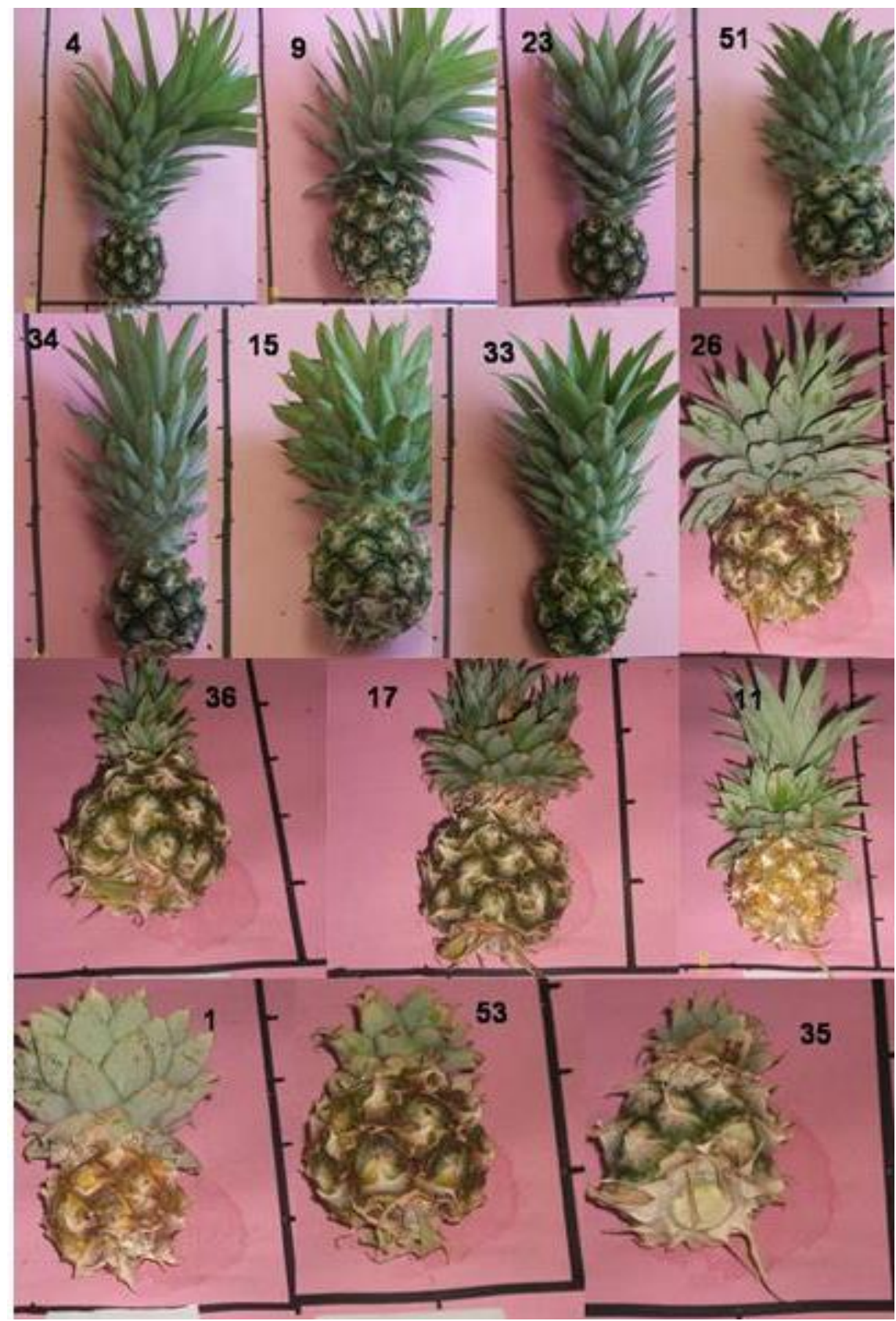

Fig. 2a. Fruit, flowers and crown morphological characteristics for various strains resulted from colchicine treatments. 


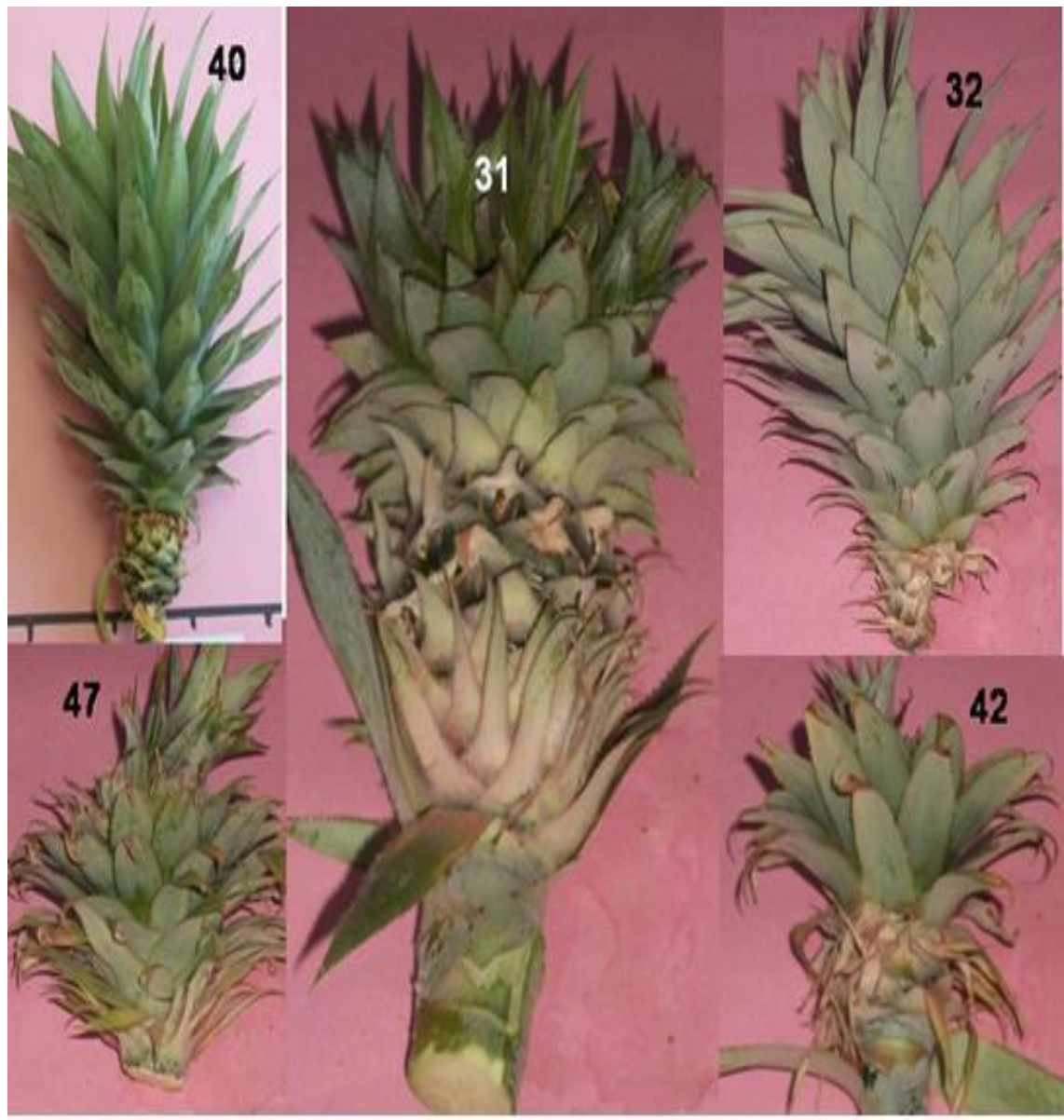

Fig. 2b. Fruit, flowers and crown morphological characteristics for various strains resulted from colchicine treatments.

\section{References}

A.O.A.C. (1960) "Official and Tentative Methods of Analysis", Washington A.D.C., USA.

A.O.A.C. Association of Official Agricultural Chemists (1985) Official methods of analysis (A.O.A.C.), Twelfth ed published by A.O.A.C, Benjamin Franklin Station, Washington D.C., USA, pp. 490-510.

Cabral, J.R.S. and de Matos, A.P. (2009) Imperial, a new pineapple cultivar resistant to fusariosis. Acta Hort. (ISHS), 822, 47-51

Egypt. J. Hort. Vol. 42, No. 2 (2015) 
Cabral, J.R.S. and de Matos, A.P. (2009) Imperial, a new pineapple cultivar resistant to fusariosis. Acta Hort. (ISHS), 822, 47-51

Cabral, J.R.S., de Matos, A.P., Junghans, D.T. and Souza, F.V.D. (2009) Pineapple genetic improvement in Brazil. Acta Hort. (ISHS) 822, 39-46

Gui, Y.L., Gu, S.R. and Xu, T.Y. (1982) Study on morphological differentiation of endosperm plantlets of Chinese gooseberry in vitro (in Chinese with English summery). Acta Bot. Sinica, 24, 216-221.

Hannweg, K. (1999) Biotechnological techniques enhance existing citrus breeding. Neltropika Bulletin, 303, 21-23.

Hannweg, K., Penter, M. and Sippel, A. (2012) Use of polyploidy in tropical and subtropical plant improvement programmes. Acta Hort. (ISHS), 935, 67-73.

Hussein, F., Dahshan, D.I., Gaafar, S.I. and Mousa, I.A. (1982) Evaluation of some date palms grown at Ismailia governorate. Fac. Agric., Zagazig Univ. Res. Bull. No. 506.

Itai, A., Tanahashi, T. (2008) Inhibition of sucrose loss during cold storage in Japanese pear (Pyrus pyrifolia Nakai) by 1-MCP. Postharvest Biol. Technol., 48, 355-363.

Joomwong, A. (2006) Impact of cropping season in Northern Thailand on the quality of Smooth Cayenne pineapple. II. Influence on physicochemical attributes. Int. J. Agric. Biol., 8 (3), 330-336.

Liu, S.Q. and Liu, J.K. (1980) Callus induction and embryo formation in endosperm culture of Prunus persica. Acta Bot. Sinica, 22, 198-199

Loeillet, D., Dawson, C. and Paqui, T. (2011) Fresh pineapple market: from the banal to the vulgar. Acta Hort. (ISHS), 902, 587-594.

Loison-Cabot, C. and Lacoeuilhe, J.J. (1990) A genetic hybridization programme for improving pineapple quality. Acta Hort. (ISHS), 275, 395-400.

Mooney, P.A., Watson, M. and Harty, A.R. (1996) Globular embryoid development in Citrus. Proc. Int. Soc. Citriculture, l, 886-888.

Mu, S.K. and Liu, S.Q. (1979) Studies on initiation of apple endosperm callus and variation of chromosomal ploidy on callus cell of endosperm. Acta Bot. Sin., 21, 309-314.

Murashige, T. and Skoog. F. (1962) A revised medium for rapid growth and bioassays with tobacco tissue cultures. Physiol. Plant., 15, 473-497.

Nady, N.H. (2010) Pineapple floral diffrentation as affected by climatic conditions, shading and plant size. Egypt. J. Hort., 37 (1)103-112.

Ollitrault, P., Dambier, D., Lofty, S., Rist, D., Mass, O., Luro, F. and Frolicher, Y. (2000) Citrus germplasm exploitation by somatic hybridization. IX ${ }^{\text {th }}$ ISC Congress Orlando Florida, 122 p. 
Ollitrault, P., Dambier, D., Allent, V. and Luro, F. (1996a) Haploid plantlets of Citrus reticulate (Clementine) obtained by induced gynogenesis. VIII ISC Congress Sun City Resort South Africa, 98 p.

Sanewski, G.M., Smith, M.K., Pepper, P.M. and Giles, J.E. (2011) Review of genetic improvement of pineapple. Acta Hort., (ISHS). 902, 95-108.

Scherer, R.F., Olkosk., D., Souza, F.V.D., Nodar, R.O. and Guerra, M.P. (2015) Gigante de Tarauacá: A triploid pineapple from Brazilian Amazonia, Scientia Horticulturae, 181 (2), 1-3.

Snedecor, G.E. and Cochran, W.G. (1980) "Statistical Methods" $7^{\text {th }}$ ed., Iowa State Univ. Press, Ames.

Starrantino, A. (1999) Tacle a new triploid Clementine x Tarocco hybrid. Rivista-diFrutticoltura-edi-Ortofloricoltura, 61, 45-47.

Thomas, T.D., Bhatnagar, A.K. and Bhojwani, S.S. (2000) Production of triploid plants of mulberry (Morus alba L.) by endosperm culture. Plant Cell Rep., 19, 395-39.

Zhang, X.M, Dou, M.A., Yao, Y.L., Du, L.Q., Li, J.G. and Sun, G.M. (2011) Dynamic analysis of sugar metabolism in different harvest seasons of pineapple (Ananas comosus L. (Merr.) African J. Biotechnology, 10 (14), 2716-2723

Zhang, J., Zhang, M. and Deng, X. (2007) Obtaining autotetraploids in vitro at a high frequency in Citrus sinensis. Plant Cell Tissue and Organ Culture, 89, 211-216.

Zhao, H.X. (1983) Plant regeneration from endosperm culture of pear. Chinese Bull. Bot., 1, 38-39. 
تقييم سلالات جديده من الاناناس ناتجه من معاملة الاناناس صنف

كايين بالكولثسين

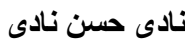

قسم بحوث الفاكهه الاستو ائيه ـ معهز بحوث البساتين ـ مركز البحوث الزراعيه ـ

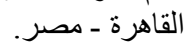

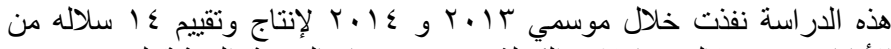

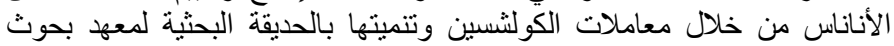

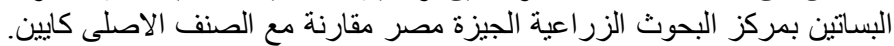

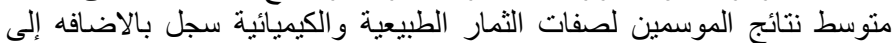

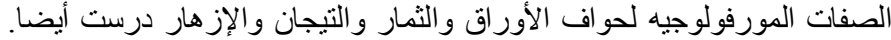

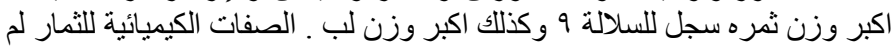

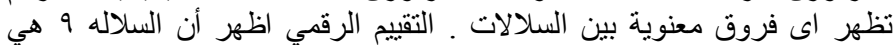

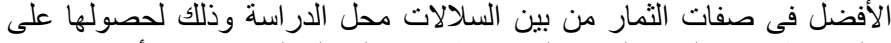

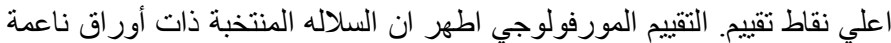

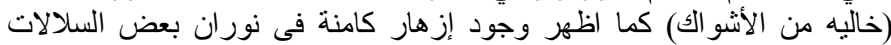

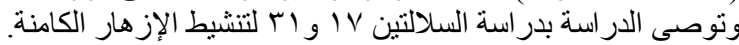

يمكن التوصيه بزر اعة السلاله 9 كأفضل سلاله ناتجة من هذه الإر اسة و أيضا

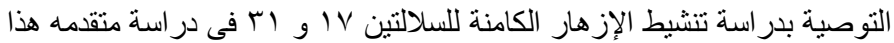

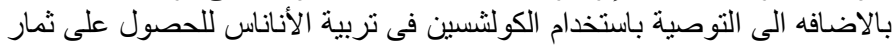

ذات حجم اكبر بنفس الصفات الكيمة بالثيائيه. 